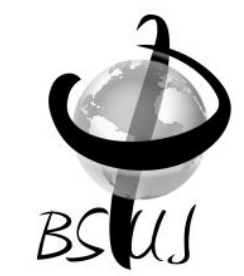

Behavioural Sciences Undergraduate Journal

\title{
Human Trafficking: The Complexities of a Global Definition
}

BSUJ 1(1)

http://mrujs.mtroyal.ca/ index.php/bsuj

\author{
Nicole MacInnis ${ }^{a}$
}

\begin{abstract}
The author of this paper explores the question, what is human trafficking? In order to answer this question, differing definitions of human trafficking are examined, as well as what problems these inconsistencies can present. Additionally, the causes of human trafficking, types of trafficking, recruitment strategies, and those whom are often targeted as victims, are discussed along with the significant problems in conquering human trafficking internationally. In order to exemplify the issues, there is further exploration into how two western countries define and approach human trafficking; emphasizing the differences between them and problems it creates. In conclusion, unless we develop a global definition of trafficking to help deal with cross-border criminal activity, we will continue to struggle with these types of trafficking problems.
\end{abstract}

Keywords: Canada, forced labour, gender violence, human trafficking, organ trafficking, sexual assault, sexual exploitation, United States, violence against women

Although human trafficking is arguably one of the oldest trades, there is not a lot of research on trafficking, and what is out there is not always the most reliable because it is virtually impossible to get consistent information on the problem. Human trafficking is often referred to as slavery in modern time, and amounts to the second largest illegal business in the world, behind arms dealing (Laczko and Gozdziak 2005; United States Department of State 2010). According to the United States Government (2006), an estimated 600,000 to 800,000 men, women, and children are trafficked globally each year. It is estimated that eighty percent of the victims are women and girls, and approximately fifty percent are under the age of 18 (United States Department of State 2010). According to the
United States Department of State (2010), United Nations estimates that 12.3 million people are forced into cheap labour, or sexual servitude, each year although some estimates are as high as 27 million. What is human trafficking?

aMount Royal University

\section{Corresponding Author:}

Nicole Macinnis

Macinnin@cc.umanitoba.ca

The above is an extremely complex question; however, first it is important to understand what human trafficking is not. Often people mistake human smuggling for human trafficking but these are not the same thing. Human smuggling is when people 
arrange to get illegal transportation over borders (United Nations 2008; Government of Canada 2010; Government of Canada 2012). The main differences between smuggling and trafficking are consent and exploitation (Government of Canada 2012). First, those being smuggled consent to the activity even though it often happens in deplorable conditions, whereas when one is being trafficked, it is not consensual (Government of Canada 2012). Note that when victims of trafficking are misled about conditions, transport, and debt, this is human trafficking. This will be discussed more, later. Second, those who are trafficked continue to be exploited once they reach their country of destination, whereas in smuggling, the person parts ways with the smuggler at the point of destination (Government of Canada 2012).

In terms of how human trafficking is defined, each nation has their own definition of human trafficking and, not surprisingly, they disagree with one another. For example, the United States does not consider organ trade as human trafficking whereas the United Nations and Canada do (United States Department of State 2010; United Nations 2013). As it will be seen, there is no agreed upon standard definition of exploitation worldwide. The United Nations tried to make a definition under the Palermo Protocol which talked about three key elements relating to intent and consent: activities (recruitment and transportation), means (how one is controlled), and purpose (the what for) (Andrees and N.J. Van der Linden 2005). However, most nations did not adopt the same definitions and it has been far from a successful universal definition of human trafficking (United Nations 2008). It will also be seen later that neither the United States nor Canada has taken this approach in their own definitions. To determine how complex defining human trafficking is, the causes, types and current definitions of human trafficking must first be explored. Then, both Canada and the United States will be looked at as short case studies to exemplify the differences and the above difficulties.

\section{TYPES OF TRAFFICKING}

What constitutes trafficking is wildly debated within countries and between countries. Agencies such as the United Nations (2008) have addressed the types of trafficking that take place globally. Most people tend to think about sexual servitude when they hear 'human trafficking' but there are other reasons people are trafficked (United Nations 2008). These purposes for trafficking include such reasons as: forced labour, military soldiers, sexual exploitation, and organ trafficking. People can be trafficked in one of two ways, either internationally, or domestically. International trafficking includes those people who are trafficked across international borders, while domestic trafficking is classified as those people who are trafficking within their country of origin. While international trafficking is still the most common form of trafficking seen, the United Nations (2012) noted that domestic trafficking is on the rise; additionally, people are also more commonly getting trafficked within their own regions. As seen in Figure 1, the United Nations (2012) examined 134 countries globally and found that domestic cases of human trafficking increased from just $19 \%$ in 2007 to $31 \%$ in 2010 , indicating that there is a shift in how people are being moved domestically as well as globally.

Fig. 1: Percent of domestic versus international trafficking cases in 134 countries in 2007 and 2010 (adapted from UN 2008 \& 2012)

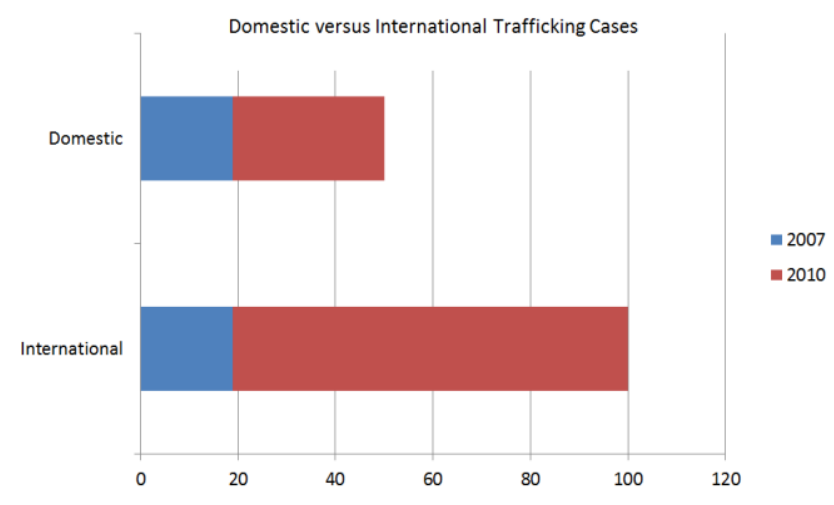


The most common form of trafficking in North America is thought to be those trafficked for the purposes of forced labour (United States Department of State 2010). On a global scale the United Nations (2009) puts the forced labour trade at $18 \%$ of all trafficking but does acknowledge that bonded labour, organ removal, domestic servitude, sexual exploitation, and warfare could be forms of human trafficking that are highly underreported. Therefore, it is possible that forced labour is also more common globally than first thought.

According to work by Andrees and Van der Linden (2005), the International Labour Organization (ILO) discusses forced labour as any work that is received from those who are under menace of a penalty. According to this reading, the ILO attempts to tackle two issues in their definition, namely the notion of a penalty, and the notion of what is consent. Further, it is emphasized that although the workers may have initially agreed to the work, they must never lose their right to free choice and must always be able to void a previous agreement with an employer (Andrees and Van der Linden 2005). In other words, if at any time the worker is not free to leave the job, then it is forced labour, even if it was a consensual agreement.

There are several forms of forced labour in the United States, with debt bondage and domestic servitude as the most common ways to trap someone in a circle of forced labour (United States Department of State 2010). Debt bondage is used to exploit workers on an initial debt that the worker assumed as part of the terms of an employment contract, but they are paid so little and their living costs are so high that they are not able to ever get out of debt (United States Department of State 2010). Domestic servitude is a more informal form of forced labour and is often linked to workers' living quarters, which are not shared with others (United States Department of State 2010). The idea behind this type of circumstance is that it socially isolates workers from other people, and this non- consensual exploitation could often lead to sexual abuse. These types of circumstances further blur the lines between types of trafficking, making it harder to decipher which types are more common (United States Department of State 2010). Although not as common as debt bondage and domestic servitude, another form of labour trafficking is child labour. This form of labour is considered only when a child is in the care of a non-custodial member who has the child perform work that financially benefits someone outside the primary family, and the child has no option of leaving (United States Department of State 2010).

In Canada, the demand for cheap labour is alarmingly increasing. According to the Government of Canada (2010)'s reading of Citizenship and Immigration Canada's (CIC) document, entitled Facts and Figures 2008: Immigration Overview of Permanent and Temporary Residents, and readings of the data contained within, namely, Total entries of temporary foreign workers by province or territory and urban area (68) comparing the years 2004 and 2008, it can be seen that between these two years there was a $330 \%$ increase in temporary foreign workers in Prince Edward Island, a $270 \%$ increase in Alberta, and a $180 \%$ increase in Saskatchewan. If one visits the CIC data first hand, it can be found that these numbers mean that between 2004 and 2008, there was a reported increase in temporary foreign workers in Prince Edward Island from 103 entries to 443 entries, in Alberta from 10,550 entries to 39,073 entries, and in Saskatchewan from 1300 entries to 3646 entries. Therefore, while the percentages put Prince Edward Island as the largest jump, it can be seen that Alberta has the largest volume of reported entries from 2004 to 2008 (CIC 2009:68). The Government of Canada (2010) further reported the finding that Alberta has the highest amount of estimated forced labourers often from: Philippines, India, Poland, China, Ethiopia, and Mexico. Specifically in Alberta, the CIC (2009) numbers indicate Calgary with the second highest volume and largest jump in 
temporary foreign workers between 2004 and 2008, from 4591 entries to 11,545 entries. Calgary is second only to a grouping of places classified as 'other Alberta'. Findings also indicated that a forced labourer earns an estimated \$0-\$600 a month and lives in shared living quarters with 5 or more people (Government of Canada 2010). These numbers together indicate that increasingly, cheap labour is overwhelmingly evident in Canada and many people living in Canada are at high risk for being forced into, and are already living, a deplorable lifestyle.

\section{Sex Trade}

According to the United Nations (2009), the sex trade accounts for $79 \%$ of those who are trafficked worldwide, and most often involves women and young girls. In simple terms, sex trafficking means "the recruitment, harbouring, transportation, provision, or obtaining of a person for the purpose of a commercial sex act" (State Department 2006:25). As with forced labour, debt bondage is a common trap for those who are sexually exploited. Women and young girls are often forced to prostitute themselves in order to try and pay off the debt they assumed when they were transported, often over international borders, for their recruitment as well as for bribes that were given to officials such as law enforcement and border guards, and sometimes traffickers will even charge the women for the price they were bought for (United Nations 2008; United States Department of State 2010). Another common form of sex trafficking is through marriage. A trafficker will trick someone into marriage and then move that person over international borders. Once they are isolated away from their country of origin, they are forced into prostitution, often in horrible conditions (United Nations 2008).

Trafficking usually takes place in underground private homes, brothels, or bawdy houses. Sometimes trafficking also happens through legal locations such as strip clubs, dance clubs, spas, and massage parlours (United States Department of State 2008).

\section{Organ Trade}

Depending on the country, organ trafficking might not be considered human trafficking. For example, organ trafficking is considered a human trafficking offense in Canada, but not in the United States. Both the United Nations and the World Health Organization have condemned the sale of human organs stating that the sale of human organs leads to exploitation and forced removal for profit (United Nations 2008). Organ trade is generally regarded as the illegal sale of human organs, often over international borders (United Nations 2008). The United Nations (2009a) speculates that the increased demand for human organs is related to aging populations in the west, a worldwide organ shortage, long waiting lists for organs, and an increased number of lifestyle related diseases such as diabetes. Take waiting lists as an example of a logical reason for the increase in global organ trade.

Figure 2. Deaths related to waiting lists for organs in the EU in 2007 (source: UN 2009a).

As shown in Figure 2, in 2007 within the European Union alone, there were 1,906 deaths of people whom were on waiting lists

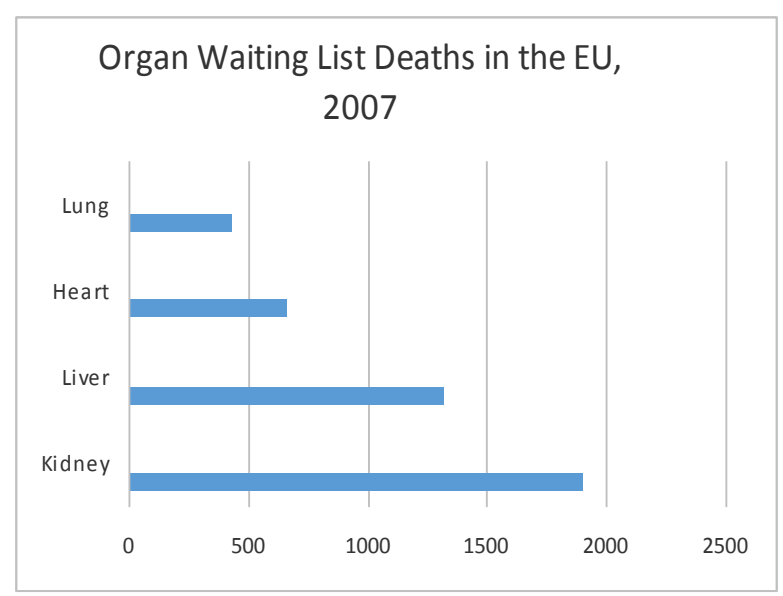

for kidneys (United Nations 2009a). These types of numbers, the United Nations (2008) believes, could be contributing to the organ trafficking problem.

Although the Government of Canada (2010) only had two complaints of organ trafficking, it would be naive to believe that 
organ trafficking does not happen in our country. However, with a great disagreement over whether this is human trafficking, and the number of borders organs cross, taken together with the fact that it is easier to smuggle human body parts than a whole human, the United Nations (2008) speculates that most organ trafficking goes unnoticed by authorities who are focused on sex exploitation in the human trafficking trade. However, the United Nations (2009a) also focuses on the possibility of the underreporting of organ trafficking. The biggest problems reported by the United Nations (2009a) are that due to a worldwide organ shortage, coupled with the amount of money one can make off of selling organs, along with the commodification of human bodies, people are reluctant to report potential trafficking and take a 'don't ask don't tell' worldwide policy on these activities.

\section{VICTIMS OF TRAFFICKING}

A joint report between the Government of Canada and the United States Government (2006), estimates that approximately 17,500 victims were trafficked into the United States annually. As seen in Figure 3, women and children are the primary victims of human trafficking, together accounting for $88 \%$ of victims in this report (United Nations 2008). Women and children are often trafficked for the purpose of sexual exploitation or slave labour, but, as also can be seen in Figure 3, men are also trafficked, usually for the purposes of forced labour (United States Department of State 2006; United Nations 2008; United Nations 2012). What is interesting is the changing dynamic of trafficking in persons. The United Nations (2012) Global Report on Trafficking in Persons shows that between 2007 and 2012 there was a slight shift in who was being trafficked. The trafficking of women slightly decreased from $66 \%$ to $60 \%$. However, this does not mean there are less female victims that are trafficked. For example, the number of girls increased to approximately $20 \%$ of victims detected by authorities that year (United Nations 2012).

Figure 3: Human trafficking victims in 2008, broken down by basic demographics (source: adapted from UN 2008).

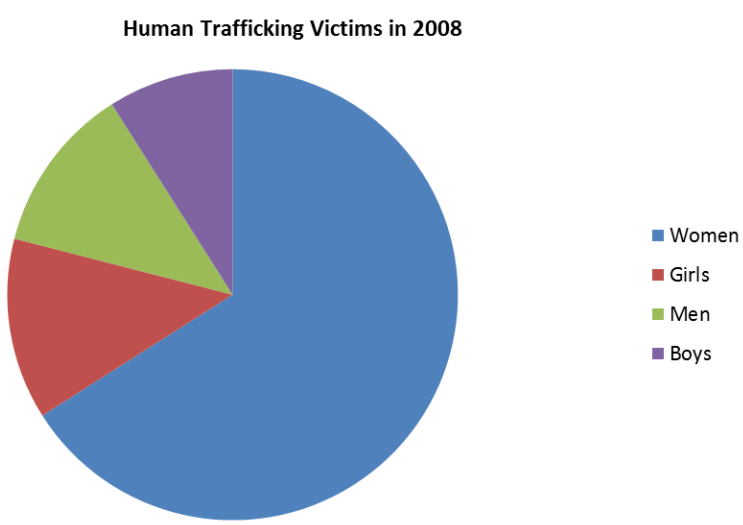

There is no doubt that trafficking is highly gendered. According to the United Nations $(2008 ; 2012)$ and the joint report done by the Governments of the United States and Canada (2006), $80 \%$ of victims are women and girls. Taken together, these facts show that women are being pushed out of developing countries into developed countries due to economic pressures in their home countries. Women often consent at first to being moved into other countries for work in order to help provide for their families back home but find themselves in abusive environments trapped in a circle of debt that is almost impossible to get out of. This is an important aspect of human trafficking as it highlights that often those who are vulnerable are targeted as potential victims, or easy targets.

A variety of high risk populations exist but women and children are among the most widely known vulnerable populations to human trafficking. Power and patriarchy are keys to this vulnerability because, as stated by the United Nations (2012), in many countries gender inequality, access to education, and work opportunities are all limited. Issues such as systemic discrimination (discrimination built into the system) make many more people vulnerable to human trafficking, such as First Nations peoples in Canada. Migrants are another 
group of people that are particularly vulnerable to human trafficking, firstly because if people are desperate to move to another country they will often look for work internationally in hopes of landing a job elsewhere. This type of search can, and does, put migrants at risk of falling into human trafficking rings (United States Department of State 2010; United Nations 2012). New immigrants are also vulnerable to human trafficking domestically as often they are under pressure to obtain work. Because many immigrants come over with little or no family, social networks also tend to be small at first; this, coupled with the need to find or maintain work makes immigrants vulnerable to trafficking rings (United Nations 2012). Therefore, although human trafficking is largely gendered and targeted, it can potentially happen to anyone. Those who are socially isolated, new to a country, desperate to leave their country of origin, or of lower socio economic statuses are all vulnerable to trafficking.

\section{RECRUITMENT OF VICTIMS}

The recruitment of people for this trade is extremely organized, and usually violent, but not always so. People are often sold to traffickers and suffer abuses to ensure control. Traffickers work in tight groups and have different methods of recruitment depending on what types of trafficking they are engaged in. Those who are trafficking for sex trade purposes will often use a victim in order to lure more people into sex trade (Walker-Rodriguez and Hill 2011). They will use a woman, or girl, whom has been in their ring for a longer period of time and can be trusted by the traffickers; she is known as the 'bottom' (Walker-Rodriguez and Hill 2011). Her job is to collect all the money from the girls, take care of anyone who is in need of discipline, and lure in more youth to the ring (Walker and Hill 2011).

Other ways that people are lured into trafficking include internet and newspaper ads. This method of attraction is most often used for the labour trade (Government of Canada 2010). For example, an ad might be placed in a newspaper claiming that there is work available where people could earn up to $\$ 10,000$ a month. Once people apply to the ads and agree to the position, they are moved over borders (willingly) but are misled about the situations they are going into (United Nations 2008). They will often be told they need to pay for the services rendered by the smuggler (moving them into the country), and further they are often charged for room and board in a debt scenario that will never allow them to pay back what they owe to the traffickers (United Nations 2008). Other times they will get to the destination country and not only be on the hook for the cost of smuggling them in, and room and board once they get there, but they will also be subject to appalling living conditions, often with multiple people to an apartment (United Nations 2008).

Finally, sometimes victims of human trafficking are brought into the country legally and knowingly. These traffickers have tremendous power over those who are victimized, often due to the victim's lower socio-economic status. For example, with relying on the trafficker's financial resources, victims are extremely vulnerable. These victims want to leave their country of origin and seek out any way to be moved out and into another country (United Nations 2008). Sometimes these people are promised legitimate work but instead find themselves in debt bondage situations. For example, according to the Government of Canada (2010), most women who are trafficked for the purposes of the sex trade are given fake identification cards in order to gain entry and legitimate employment in the country of destination. Often, these women are diverted to exotic clubs, and are recruited by acquaintances or the internet (such as through craigslist ads), and are then manipulated into the industry (Government of Canada 2010).

\section{CONTROLLING VICTIMS}

In order to be successful traffickers, perpetrators must be able to control their 
victims in all aspects of the process, especially when crossing multiple international borders. In the following, several common methods that traffickers use to ensure their victims arrive at the destination country will be discussed. Sometimes traffickers will use one method, and other times they may use a combination of methods to ensure success.

\section{Threats and Violence}

Coercion is a common method of control that perpetrators use over victims. It often involves threats of serious harm or some kind of physical restraint of the body (United States Department of State 2006). Coercion could also be a method that is intended to make someone believe that if they did not comply with their traffickers it would result in physical harm against them (United States Department of State 2006). And finally, coercion could involve threating a victim with legal action if they do not submit to their trafficker's demands (United States Department of State 2006). Further common threats of violence are threats against friends and family members of the victims (United Nations 2008). Traffickers will threaten family of the victims ensuring that their victim will not run, and will continue to comply with demands to keep their loved ones safe.

\section{Financial}

Traffickers control their victims through a variety of means including use of force or violence, drugs, emotions, financial control, threats of deportation, and threats to their families that have been left behind back home, often in poor countries (Government of Canada 2010; Government of United States and Canada 2006). It is not uncommon for traffickers to establish bonds with the girls they are bringing in to a country for the purposes of prostitution (Walker and Hill 2011). By doing this, traffickers create a need in the girls to depend on them in order to ensure that the girls remain in their control. Traffickers often pose as a boyfriend or husband to get them into the country and once here will move them into a prostitution ring (Verhoeuen and Gestel 2011; WalkerRodriguez and Hill 2011). This love affair between captor and victim is also a means of control over the victim as they come to believe that the work they are doing are favours to their 'boyfriend' (Government of Canada and United States 2006; United Nations 2008; Verhoeuen and Gestel 2011). As a result of these methods, victims are often worked six days a week and are controlled through the use of financial issues, the inability to speak the native language of the country they are in, or through the use of indebtedness (an incurred debt that continues to get larger the longer they stay with their captors) (Government of Canada 2010).

\section{Displacement}

Displacement is a type of control that involves moving people into an unfamiliar environment. Moving people from their country of origin to a country where labour demands are high is not only profitable for a trafficker, but it is also a means of control over their victim. By moving a victim into an unfamiliar environment the victim is more vulnerable (United Nations 2008). Victims may have a lack of cultural understanding, they may not know the language to be able to ask for help, and they are often controlled by being physically isolated from other people (United Nations 2008). Further, they may come from a country where there is a mistrust of authorities, often because of corruption, and therefore they may be more fearful of law enforcement in the new country than in their captors' country (United Nations 2008). Victims also may have a lack of legal knowledge. For example, victims may not understand their rights in the country they have been brought into and if that is combined with a mistrust of local authorities it is the perfect control mechanism for a trafficker to ensure their victim will comply (United Nations 2008). 


\section{REASONS FOR HUMAN TRAFFICKING}

It is easy for traffickers to recruit people when one takes the above circumstances into account. While the reasons for human trafficking are complex, the scope of the current paper touches only on some salient arguments. For example, some causes are arguably based partially on push and pull factors (Government of Canada and United States 2006). Push factors are those factors in the environment that drive someone toward traffickers. These could include poverty, inadequate social programs, and unemployment in a victim's country of origin. If people are struggling to get jobs, support their families, or lack a safety net, they are more vulnerable to scams and victimization brought on by traffickers. Other common push factors include: conflict, war, or political unrest (Government of Canada and United States 2006). The unstable conditions that such factors cause in a home country also cause fear and instability that are likely to make the 'American dream' seem attractive, resulting in people becoming desperate to start a life in a stable war free country where they are promised the opportunity to make money and support those they care about (Government of Canada and United States 2006).

Pull factors drive victims towards specific countries of destination (Government of Canada and United States 2006). In other words, pull factors are those factors that provide the need, or demand, for human trafficking. There are two big pull factors including firstly the globalized free market that causes and increases demand for cheap labour, and secondly new technology (Government of Canada and United States 2006). Due to the consumption habits of first world nations such as the United States and Canada, consumerist ideology has been reinforced and become a cultural phenomenon. Due to this, it could be argued that there has been a strong increase in the demand for cheap labour; therefore motivation exists for traffickers to make money, and for victims to have the chance to start a new life in a different country (United
Nations 2008; United Nations 2009a).

\section{ROUTES TRAFFICKERS USE}

Trafficking routes are complex, and often stretch across numerous borders, making conviction extremely complicated due to jurisdiction disputes. This international trafficking often spreads across several countries where traffickers continuously change routes and re-establish their business (Government of United States and Canada 2006). New routes are developed as old ones collapse. Routes are designed as complex networks that involve establishing safe houses and receivers along the routes at connection points (Government of United States and Canada 2006). Some of these routes are already established as they are also used by drug and weapon smugglers (Government of United States and Canada 2006). The routes can change in an instant and are often run on interchangeable networks. There are several types of networks, including small informal networks and medium sized networks (United Nations 2008). Small informal networks are those networks that actually move people into new countries and they are often through small clubs in destination countries that help recruit people, mostly women for the purposes of the sex trade, over borders. These small networks perform the jobs of contacting recruits, accompanying them into the new country, and then leaving them with buyers. The medium sized networks operate along fixed routes and they do not sell anyone, but instead simply put people to work on the route in clubs, bawdy houses, and brothels (United Nations 2008).

\section{CASE STUDY: A QUICK COMPARISON}

In order to demonstrate the difficulties in defining just what human trafficking is, the present paper will compile and present key definitions and statistics from two countries, on the same continent, to examine just what they believe human trafficking is. In 2006, the United States and Canada compiled a joint government 
document of statistics and definitions of human trafficking that was both confusing, and contradictory, ultimately adding to the confusing literature on the topic. Consequently, this key joint report, alongside other reports, gives introductory background to the topic while attempting to outline the problems with this information at the same time. Using these sources it will now be seen how it is currently so difficult to come up with a universal definition of human trafficking in the first place.

\section{Canada}

The Government of Canada (2010) defines human trafficking as involving "any person who recruits, transports, transfers, receives, holds, conceals or harbours a person, or exercises control, direction or influence over the movement of a person for the purpose of exploiting them or facilitating their exploitation" (p. 8). Canada's legislation defines two types of trafficking, namely international and domestic trafficking. International trafficking involves someone who, in the process of being trafficked, is moved over international borders (Government of Canada 2010). Domestic trafficking is all stages of trafficking that occurs within Canada (Government of Canada 2010). People who are trafficked to Canada primarily come from Asia, Thailand, Cambodia, Malaysia, Vietnam and those who are trafficked through Canada primarily come from Africa and Eastern Europe (Government of United States and Canada 2006). People are moved by individual contractors through land entry points, marine points, and airports (Government of United States and Canada 2006). Those who remain in Canada head to larger urban areas such as Toronto, Montreal, Calgary, Edmonton, Vancouver, and Winnipeg (Government of United States and Canada 2006). Some victims are trafficked with their knowledge, agreeing to pay as much as $\$ 50,000$ to be brought into the country, often unaware of the treacherous conditions awaiting them (Government of Canada 2010). Ontario also serves as a gateway to the United States for those victims who do not remain in the country (Government of Canada 2010). In Canada it is estimated that $600-800$ people are trafficked per year and that between 1500-2200 victims are trafficked through Canada to United States destinations per year (Government of United States and Canada 2006). As of April 25th, 2012, there were 25 convictions total that year alone in Canada related to human trafficking and $90 \%$ of those cases were for domestic trafficking (Government of Canada 2012).

Prostitution rings are common in Canada and often are facilitated out of Eastern Europe (Government of Canada 2010). These women are trafficked using fraudulent passports or visas and Canada also has an influx of migrant workers who often enter Canada through visitor visas, often agreeing to pay a fee to the traffickers (Government of Canada 2010). Once their visas expire, these people leave the country voluntarily, sometimes opting to come back at a later date (Government of Canada 2010). According to the Government of Canada (2010), Eastern European women who have been trafficked mostly end up in clubs in Toronto and Montreal whereas those whom are recruited from Asia are usually recruited into bawdy houses and massage parlours in western Canada (Calgary, Vancouver, Edmonton), and are usually between the ages of 21 and 38.

\section{United States of America}

According to a review of the literature done by Gozdziak and Collett (2005), the first definition of human trafficking in the United States was created by the President's Interagency Council on Women, and defined trafficking as "all acts involved in the recruitment, abduction, transport, harbouring, transfer, sale, or receipt of person, within national or across international borders through force, coercion, fraud, or deception; to place a person or persons in situation of slavery or slavery like conditions, forced labour, or services, such as prostitution or sexual services, domestic servitude, bonded sweatshop labour, or other debt bondage" (Gozdziak and Collett 
2005:105). According to the United States Department of State (2006), this definition was later replaced with a legal definition created by the Victims of Trafficking and Violence Protection Act that defined trafficking in two ways. The first was a definition of sex-trafficking that defined sexual servitude as a sex act that is induced by force, fraud, and coercion, where the person has not reached the age of 18. Also included in the definition were the recruitment, harbouring, and transportation of people for the purposes labour or services, through the use of force, fraud, or coercion for involuntary servitude, debt bondage, or slavery (United States Department of State 2006).

In the United States, victims most often come from Latin America, Asia, Africa, and Eastern Europe (Government of United States and Canada 2006). Those coming from Latin America, Asia, and Eastern Europe are more often trafficked into the commercial sex trade (Government of United States and Canada 2006; United States Department of State 2010). Further, a majority of the victims are trafficked through Canada and end up in a major city in the United States for labour exploitation, or the sex trade (Government of United States and Canada 2006).

\section{SUMMARY AND CONCLUSIONS}

An example comparison between the United States and Canada's definitions of human trafficking above showed that the definitions are not in line, which seems to be related to the variations exemplified above in between border factors. In order to examine potential solutions to the problem, one must go back to the root causes of the problem to begin with. These root causes, as stated earlier, could include such things as economic downturns (in countries of origin), poverty, political unrest, lack of clear definitions, and a severe lack of enforcement of trafficking laws that are currently in place. Although defining human trafficking is extremely complex, there has been an $80 \%$ increase in countries developing legislation on the issue (United
Nations 2012). However, enforcing these laws and convicting people involved in trafficking is a global problem because of current cost and reward perceptions. In other words, human trafficking must be changed from a low risk, high reward activity into a high risk, low reward activity. For example, the Government of Canada (2010) estimated that escort services could bring in as much as $\$ 6000$ per week for four clients being serviced six days a week. This change can start to happen by prosecuting more offenders. According to the United Nations (2008; 2012) prosecutions and convictions are low to non-existent globally (refer to Figure 4). Out of 132 countries, the United Nations (2008; 2012) collected the following information: $18 \%$ said there was no data available, $16 \%$ stated no convictions, and only $18 \%$ stated more than 50 convictions over the period of one year. Although legislation has been put in place in many countries over the last decade, due to the complexity of defining human trafficking and the lack of enforcement, convictions are extremely low globally.

Figure 4. Percentages of actual convictions of human trafficking (source: adapted from UN 2008; 2012).

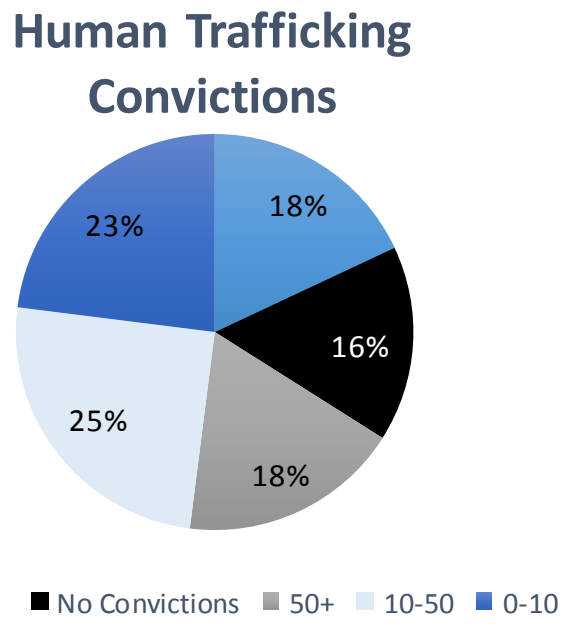

What is interesting is who is getting convicted for human trafficking offenses. Women account for approximately $30 \%$ of 
convictions (United Nations 2012). This is interesting because it is known that women account for, on average, about $15 \%$ of crime and those crimes tend to be non-violent crimes (United Nations 2012). This conviction rate can be explained by the gender inequality and women's vulnerability globally. Women are often used in more vulnerable areas of the trafficking rings, and are therefore more likely to be exposed to law enforcement officials. This often includes the recruitment processes, travelling with victims, and sometimes, women who are victims themselves are placed in supervisory positions in sex trafficking rings where they are supposed to collect money from the other women (United Nations 2008; United States Department of State 2010; United Nations 2012).

In light of the above analysis, it is seen that clearer definitions must be developed so that countries can focus on prosecuting traffickers in order to tackle the human trafficking problem. Furthermore, inconsistencies in defining what exactly human trafficking is have led to the problems in preventing it. This is because human trafficking is a cross-border criminal activity that often, though not always, involves moving people over multiple border crossings and therefore involves dealing with inconsistent legislation. This simple fact contributes to the seemingly unrealistic goal of creating a universal definition of human trafficking, but we will continue to struggle greatly until we can at least globally decide exactly what human trafficking is. A next step would be to then prosecute traffickers based on a consistent definition. This would help create a stronger perception of higher risk and lower benefit to traffickers. Further, in an attempt to prosecute more offenders, a global effort must be made to share information to build cases against those whom traffic over multiple borders. Additionally, on a more grand scale, effort should be made to tackle poverty, inequality, and gender violence globally in order to decrease the vulnerability of women and children as well as all victims of trafficking. Finally, a reasonable effort must be made on the educational and research side of human trafficking in order to change the consumption habits on the part of consumers. As long as there is a demand for cheap goods, bodies will continue to be commodified for profit.

\section{References}

Andrees, B. Van der Linden, N.J M. 2005. "Designing Trafficking Research from a Labour Market Perspective: The ILO Experience." International Migration. 43(1-2):55-73.

CIC, Citizenship Immigration Canada. 2009. Fact and Figures 2008: Immigration Overview; Permanent and Temporary Residents. Retrieved from http://www.cic.gc.ca/english/pdf/res earch-stats/facts2008.pdf

Government of Canada. 2010. Human Trafficking in Canada. Ottawa, ON: Canada. Retrieved from: http://publications.gc.ca/collections/ collection 2011/grc-rcmp/PS64-782010-eng.pdf

Government of Canada. 2012. National Action Plan to Combat Human Trafficking. ON: Canada. Retrieved from: http://www.publicsafety.gc.ca/prg/le L fl/cmbt-trffkng-eng.pdf

Government of United States \& Canada. 2006. Bi-National Assessment of Trafficking in Persons. Retrieved from: http://www.publicsafety.gc.ca/prg/le $\angle$ fl/1666i-en.pdf

Gozdziak, E., Collett, E. 2005. "Research on Human Trafficking in North America: A review of the Literature." International Migration. 43(1-2):99128.

Laczko, F. Gozdziak. 2005. Data and Research on Human Trafficking: A global Survey. International Organization for Migration 43.

United Nations. 2008. An Introduction to Human Trafficking: Vulnerability, Impact and Action. United Nations Office on Drugs and Crime. Retrieved from: 
http://www.unodc.org/documents/h

uman-

trafficking/An Introduction to Huma

n Trafficking - Background Paper.pdf

United Nations. 2009. Anti-Human Trafficking

Manual for Criminal Justice

Practitioners. Retrieved from:

http://www.unodc.org/unodc/en/hu

man-trafficking/2009/anti-human-

trafficking-manual.html

United Nations. 2009a. Trafficking in Organs, Tissues and Cells and Trafficking in Human Beings for the Purpose of the Removal of Organs.

United Nations. 2012. Global Report on Trafficking in Persons. United Nations Office on Drug Crimes. Retrieved from:

http://www.unodc.org/documents/d ata-andanalysis/glotip/Trafficking in Person s 2012 web.pdf

United States Government. 2000. Victims of Trafficking and Violence Protection Act of 2000. Retrieved from: http://www.state.gov/i/tip/laws/61 124.htm

United States Department of State. 2006. Trafficking in Persons Report. Washington, DC: USA.

United States Department of State. 2010. Trafficking in Persons Report. Washington, DC: USA.

Walker-Rodriguez, A. Hill, R. 2011. "Human trafficking." Federal Bureau of Investigation Law Enforcement Bulletin. Retrieved from: http://www.fbi.gov/statsservices/publications/lawenforcementbulletin/march 2011/human sex traf ficking 